\title{
A View on the Treatment of Collusive and Restrictive Practices in Competition Policy
}

\section{W D Reekie}

E P Bradlow Professor, Department of Business Economics, University of the Witwatersrand

\section{ABSTRACT}

South African competition policy is in a state of flux. While professing to serve so-called national interest, legislation has tended to overlook the principles of economic efficiency and consumer welfare. The South African National Drug policy is a case in point. The best defence against collusion and restrictive practices in business is competition, but the Department of Health favours blanket rules like uniform pricing and a fixed fee-for-service. Thus supermarkets may not employ dispensing pharmacists, and uniform price legislation would make it illegal to negotiate discounts on prescription medicines with retailers. As a rule consumers are the losers. Many fallacies are contained in the debate on the "right" competition policy for South Africa. For example, a firm may appear big simply because the domestic market is small.

\section{INTRODUCTION}

This paper begins with a brief overview of South African Competition Policy since 1979. In particular, the approach of the Competition Board to restrictive practices and collusive behaviour, rather than towards monopoly or merger activity, is detailed. Four main manifestations of what is sometimes regarded as evidence of restrictive practices are then discussed. These are the presence of parallel pricing, the favouring of associated firms, predation, and price discrimination. The Board has recently decided against the Cement Producers cartel. Some writers (e.g. Leach, 1994) have argued that the decision was inappropriate given both the guidelines of the Act and the theory of cartels. Conversely, this paper shows how the Board has consistently refused to pronounce against another long standing cartel, the retail pharmacists. Again appropriate appeal to the Act and use of economic theory could have been used to suggest that this stance also is in error. 
In this section of the paper reference is made in particular to Competition Board Report, No 52, 1996. The paper concludes with some general thoughts on the future direction of Competition Policy legislation.

\section{CURRENT SOUTH AFRICAN POLICY - A BRIEF REVIEW}

The Maintenance and Promotion of Competition Act of 1979 enables the Competition Board to examine three main aspects of business, namely monopoly situations, acquisitions and restrictive practices. Its definition of a monopoly situation is broad:

... a situation where any person, or two or more persons with a substantial economic connection, control in the Republic or any part thereof, wholly or to a large extent, the class of business in which he or they are engaged in respect of any commodity.

So too is its definition of acquisition:

... the acquisition by the holder of a controlling interest in any business or undertaking involved in the production, manufacture, supply or distribution of any commodity, of such an interest --

(a) in any other business or undertaking so involved; or

(b) in any asset which is or may be utilised for or in connection with the production, manufacture, supply or distribution of any such commodity, provided such acquisition has or is likely to have the effect of restricting competition directly or indirectly.

However, the "acquisition" definition is more precise in that it relates to "restricting competition". The definition of "restrictive practice" is also helpful, and again the criterion required for implicit condemnation is the restriction of competition. Restrictive practice means:

- any agreement, arrangement or understanding, whether legally enforceable or not, between two or more persons; or

- any business practice or method of trading, including any method of fixing prices, whether by the supplier of any commodity or otherwise; or

- any act or omission on the part of any person, whether acting independently or in concert with any other person; or

- any situation arising out of the activities of any person or class or group or persons, 
which restricts competition directly or indirectly by having or being likely to have the effect of -

- restricting the production or distribution of any commodity; or

- limiting the facilities available for the production or distribution of any commodity; or

- enhancing or maintaining the price or any other consideration for any commodity; or

- preventing the production or distribution of any commodity by the most efficient and economical means; or

- preventing or retarding the development or introduction of technical improvements or the expansion of existing markets or the opening up of new markets; or

- preventing or restricting the entry of new producers or distributors into any branch of trade or industry; or

- preventing or retarding the adjustment of any profession or branch of trade or irdustry to changing circumstances.

It took three years (as demonstrated by the Board's Annual Reports) for the Board to tilt its interpretation of its definition of monopoly to the structural rather than a behavioural one. The same period saw the "public interest" concept added in such a way that consumer welfare ceased to be the ultimate yardstick of whether or not a monopoly situation was to be condemned.

The First Annual Report of the Competition Board (1980, para 11) highlighted points regarded as crucial. The Minister of Economic Affairs was quoted thus:

- $\quad .$. preservation of the free market system ... is the cornerstone of our ... economic life [and]

- $\quad .$. the preservation of healthy competition ... [is] an important condition ... [for] economic development.

To achieve these ends the Board was established to help implement the 1979 Maintenance and Promotion of Competition Act to:

- ... provide for the maintenance and promotion of competition;

- ... [prevent] or control restrictive practices;

- $\quad$... [prevent or control] the acquisition of controlling interests in businesses and undertakings; [and]

- ... [control] matters connected therewith (para 12). 
In short, market concentration (smallness of firm numbers and largeness of firm size) was not included in the Board's terms of reference. Within a year, this constructive approach to competition and sober approach to big business had altered. The Second Annual Report (para 9) said:

Oligopolies ... [can cause] prices to congeal at unduly high levels, while conglomerates can distort competition by ensuring market support for their members at the cost of more efficient outside firms. Clearly, these oligopolies and conglomerates should be under constant scrutiny so that possible abuses can be detected and, where necessary, corrected in the public interest.

The Board's Third (1982) and Fourth (1983) Annual Reports took similar positions (paras 16-17 and 12-13 respectively) and the latter (para 14) explained why:

Market conduct is never unrelated to market structure ...[so] both are of the utmost importance for the efficient implementation of competition policy.

Thus South African competition policy in its very early years was designed to take account primarily of the newer thinking in industrial economics, which downplayed the importance of structure as a criterion. However, after 1982. structure, in contrast to the more permissive policy abroad, emerged as a key criterion for investigation.

Moreover, although not detailed in the original Act, the Board came to view the "public interest" rather than the consumers" interest as the "final criterion" in judging a monopoly or a merger. It has proved difficult for the Board, however, to agree on what the public interest is. This makes its judgements unpredictable and creates uncertainty for consumers and producers alike. One chairman of the Board (Dr D Mouton, in 1982) defined it as "the interest of consumers, producers and traders as well as the broad national interest". The national interest in turn was defined as achieving

...economic growth, the efficient utilization of resources, an acceptable pattern of income distribution, a desirable general price level, and equilibrium in the balance of payments.

In practice, when the Board has tried to apply this criterion its verdicts have not been consistent. This is not surprising since the definitions embrace groups whose interests do not necessarily coincide, and economic goals which may be mutually exclusive. Not only are the Board's reports sometimes inconsistent in how they interpret the public interest, but even in the same report members of the Board may express disagreements in minority reports.

The mechanistic structuralist approach towards monopoly did not survive long. The second chairman, Dr $S$ Naude, argued for a less structurally 
constrained approach, though he also emphasised the "public interest" as a criterion. He stressed that effective competition was independent of market structure: "It could include both the extremes of atomistic competition ... and the oligopolistic market structure with a few large dominant firms." He went on to define effective or workable competition as "a market situation that (a) holds the essential benefits of competition such as freedom of entry ... a choice for buyers and the inability of sellers to impose terms (including prices) on buyers; (b) is practical, i.e. workable; and (c) can be reconciled with the public interest". In 1986, Dr Naudé noted the counter-revolution that had taken place recently in US policy and ascribed it to, inter alia, the increased influence of economic analysis. He quoted a leading US anti-trust jurist, Judge Robert Bork, who expressed the "hope that the process will continue until this body of the law becomes completely economically rational".

At present in the 1990s, however, it appears as if the economic analysis which is applied is based on both approaches, which have quite different policy implications. The Competition Board still has some way to go in applying consistent criteria in its decisions and recommendations. This policy ambivalence was highlighted by the approach adopted towards restrictive practices, also in 1986. Per se prohibitions of certain agreements were introduced as additions to the 1979 Act (including resale price maintenance, horizontal price collusion and collusion on conditions of supply). Exemptions could be granted if it could be shown that the agreements were in the public interest, whereas generic restrictive practices in the original Act were "restrictive" only if they restricted competition as defined, not simply because they existed per se. Restrictions against the interest of consumers can certainly occur - the point is, either they do not persist or else they arise because they are, in fact, means of lowering costs and therefore prices to consumers. Per se prohibition denies consumers the opportunity to discover if this is true.

Now, in the late 1990s, a major review of South African policy is contemplated, prompted by political, structural and populist concerns. If economic and consumer-interest criteria were regarded as the only relevant considerations, such a root-and-branch examination would not be necessary. Before concluding with out own recommendations for reform, we examine some of the concerns already detailed from the Second Annual Report. (Namely prices which are held at "congealed" levels and "market support" for conglomerate members by use of discriminatory practices.) 


\section{Parallel and uniform prices}

To some theoreticians uniform prices are a result of collusion and are to be expected because of concentrated industrial structures. This theory does not stand up to examination.

"Parallel pricing" is the practice by which two or more sellers set their prices at or about the same level and change them at or about the same time and by the same amount or proportion. The important matters that need to be established are whether this form of behaviour is competitive and/or if it can be expected to have consequences which may be detrimental to the public interest as measured by consumer welfare. Areas in the $1990 \mathrm{~s}$ where this has been of concern to the Competition Board include cement prices, bank interest rates, retail pharmacy selling prices and cellular phone rates.

In the perfect competition of elementary theory no individual seller is able to influence the market price. Market price is determined impersonally by the interaction of the total supply of the product and the total demand. The individual seller is a "price taker" in that he or she cannot influence the price by his own actions. It is in this sense that these markets are customarily described as perfectly competitive. Sufficient conditions are a large number of sellers (and indeed of buyers), all of substantially similar size, standardisation of different sellers' products, and a high degree of knowledge of market prices among sellers and buyers. These conditions prevail in various commodity and financial markets. In such markets the price charged by all sellers will be uniform. No individual seller will be able to charge more than the market price or will wish to charge less than that price, whatever his own costs. Changes in demand conditions in the market, or in the costs of all or a significant number of sellers, will result in prompt change in the market price since all sellers will find it to their advantage to charge the price at which total supply and total demand are balanced in the new condition. The fact that sellers' prices change at or about the same time and by the same amount in these circumstances would be evidence of a highly competitive situation. Moreover, with the further condition that entry of new sellers into such markets is easy, there would be no reason to expect the rate of profit to deviate for long from the minimum necessary to attract investible funds, given the risks involved. We can call this rate of profit the "competitive" or "normal" profit. Observed profit rates in such markets may display fluctuations and may not correspond to the normal rate at any one time. But there can be no long-run tendency for profit rates to remain above the competitive level.

In a situation of economic - not legal - monopoly (a single seller), there will also be a uniform price since there will be only one price and one product. The decision-taker in such a situation has a more difficult job in setting prices than the 
"price-taker" of perfect competition. He or she cannot accept the market price (since there isn't one) but must choose by more or less informed trial and error what is believed to be the wealth-maximising price. Selection of a price above or below that level will result in a wealth loss. Furthermore, there can be no presumption that the wealth gained by selling at the (unknown) optimal price will be at a level above "normal profit". Provided others can readily enter the industry (provided it is a "contestable" market), the monopolist's wealth-maximising prices will be constrained and his capital will earn only the competitive rate of renurn. Contestability requires not large numbers of firms, but only easy and low-cost entry and exit. An incumbent monopolist cannot charge a high price and succeed in earning returns above the competitive norm in a contestable situation. He will instead be subject to competition from a new entrant, so destroying the monopoly. Alternatively, the threat of such entry, or the effect of actual hit-and-run entry, will be such as to bring price and returns down to the competitive level, leaving the economic monopoly intact.

Concern about monopoly arises when entry is barred in some way - say by government regulation. The incumbent can then charge a higher price, earn higher returns, and provide consumers (because of the higher price) with lower volumes of the commodity than they would otherwise purchase at more competitive levels. In addition, any spur to higher efficiency or innovation may be blunted.

Uniform or parallel prices can thus be regarded as the competitive norm whether a diffuse or a single-seller structure is considered. Similarly, returns or profits can be regarded as appropriate in either siuation (with the added requirement of contestability in monopoly).

It is when we turn to markets which are not characterised by a large number of sellers that we may encounter a practice which gives rise to concern, that is, collusive parallel pricing. Industries with relatively few sellers, or in which a few sellers dominate the market, are generally termed oligopolistic. In modem economies a considerable number of markets are oligopolistic. The distinctive feature of oligopolies is that a major decision by one seller will have a significant effect upon the other sellers and that the reactions of those sellers will in turn affect him. Recognition of these interdependencies may deter the individual seller from self-interested price changes which must be made at the expense of competitors. Instead, pricing policies may be co-ordinated with the aim of balancing the interests of all the sellers as a group. Price changes may then be initiated only when there is good reason to expect that all sellers will benefit, whether the change is upwards or downwards. 
In short, the sellers may try to act in collusion, tacitly or explicitly, as if they were an economic monopoly. This is often termed collusive or cartel behaviour. Decisions are taken with group welfare in mind, rather than being prompted by a rivalrous desire to get one step ahead of the competitors. The belief is that pro rata shares of profits resulting from group wealth-maximising behaviour will be greater than would accrue if individualistic, but self-defeating, motivations dominated. The social costs of noncontestable monopoly would therefore accrue.

In fact, as opposed to belief, firms will collude only if the expected benefits are greater than the expected costs. The costs of collusion may prevent any attempt to collude. An attempt to collude may fail and, indeed, typically will fail as discussed in the following paragraphs. Moreover, even a successful collusion will be far from perfect and so the colluding firms will still fail to act as if they were a monopoly. These assertions are now examined more closely. George Stigler's view of cartels was that they are either tacit or explicit agreements which, because of rivalry, seldom last. 'They are gentlemen's agreements: where they seldom are or long do.' Collusive parallel pricing is understandable but it will not persist (see Stigler, 1966, Ch 13). There are several strands to the argument.

- Individual firms will always have an incentive to chisel or cheat on any explicit or implicit price agreement.

- Such cheating will quickly be noticed and responded to by competing price reductions (leading to non-collusive uniform prices providing normal renurns).

- To guard against chiselling firms may set up monitoring mechanisms (of each other) or allocate shares of market or territories for exclusive use. This is costly and/or agreement may be difficult. The less likely outcome is agreement (e.g. efficient firms do not like feather-bedding inefficient ones, each likes a "fair" share of profits and "fairness" is difficult to define) the more likely outcome is cartel breakdown.

- Cartel breakdown by chiselling (price rivalry) is also more likely the higher is the ratio of fixed to total costs in an industry. Given a relatively high burden of fixed costs, a "voluntary" diminution of the tlow of cash revenues (by "agreeing" to high uniform prices and claiming to forgo chiselling) inay create financial difficulties. This is particularly true in times of market depression -- or its supply-side corollary, capital outlay growth.

- Further, cartel breakdown through cheating (price rivalry) is also likelier in a rapidly growing industry. If demand is rising fast, other things equal, the likelihood of being instantaneously spotted cutting price will appear to be less. The impact on rivals' current outputs need not now be negative - you 
may merely slow their rate of growth. Rivals, of course, each reason in the same way, and the collusion crumbles.

- If existing firms do not cheat and pull prices down to lower (but still uniform) levels, then as in contestable monopoly, new firms will enter and achieve the same result. Indeed even the threat of their entry can have this result. (Again, as in monopoly, the situation must be contestable, and entry easy to activate.) As with perfect competition and contestable monopoly, uniform parallel prices and the profits derived therefrom simply represent convergence on the competitive norms.

This analysis can be applied to most if not all so-called collusive areas of industrial practice. Collusion may be an instinctive behaviour pattern for many businessmen but competitive forces rob them of their ability to indulge it. Award government protection, however, and new forms of competitive behaviour, new rivals, new entrants, and "cheating" by existing competitors can be ruled out by law. Consumers need reflect only on the cartels protected by government to see how easily they could be better off. (Medicines and petrol prices are only two examples of the results of outmoded distribution channels protected by government; Clicks may not employ dispensing pharmacists and Pick 'n Pay may not cut petrol prices.)

\section{Favouring associated firms}

The charge that large pyramidal or conglomerate firms selectively favour associated companies for monopolistic reasons is very unlikely in theory. Judge Bork in his analysis of anti-trust in the USA points out that "it is impossible for a firm actually to sell to itself for less than it sells to outside firms because the real cost of any transfer ... includes the return that could have been made on a sale to an outsider. No matter what the bookkeeper writes down as the transfer price, the real cost is the opportunity foregone." (If I am a dressmaker buying in fabric at R50, selling completed dresses at R100, and 1 give a new dress to my wife, my cost is R100, not RSO, no matter what figure 1 put in my books.) Subsidising associated firms, if it occurred, would be self-deception, involving sacrifice of returns, and merely providing encouragement to the associate to operate at an uneconomical rate. (See Bork, 1993, p.228.) Cross-subsidisation cannot increase existing returns, nor can it enhance any above-normal or monopolistic returns. As Judge Bork points out (p.229), above-normal returns can be abstracted only once from the value chain and as we have already seen, firms cannot, unless protected 
by government in one way or another, act as if they were monopolists in any event.

Bork (p.229) demonstrates this by looking at an integrated manufacturer and retailer. If each tries to maximise profit by restricting ourput, the result will be a price higher and an output smaller than the monopoly point. (My own text, Managerial Economics, 1995 , contains several pages of rules managers can apply in their own interests to avoid this unhappy outcome.) The rationale starts by looking at a monopoly manufacurer selling to competitive retailers. The manufacturer will set output and price so that consumers will be charged the monopoly price after retailers have added their costs, including a normal return. The manufacturer will not want retailers to earn more (since that would be foregone profit), nor will he want them to earn less, since then retail investment and so throughput would ultimately decline to the manufacturer's detriment. Similarly, if retailers earned more and so expanded, the manufacturer would be paying for unwanted retail services.

If the manufacturer takes over the retail sector, the demand he faces and costs he would incur will be unchanged. His profit-maximising output decision will thus also be unchanged. There is only one monopoly profit.

\section{Predation}

The only other reason for fear of monopolistic abuse by cross-subsidisation is predation: that is, the intent to drive independent firms out of business either by a direct price war or by selling inputs to associated firms at such low prices that the associates can indulge in a price war. After a successful price war prices can be raised to monopolistic levels. If this is the case, of course, it immediately suggests that firms so accused cannot be currently abusing their market positions (monopoly returns can be abstracted only once in the value chain). Once achieved, any subsequent verical relationship could be examined for abuse in due course. Ex post analysis, however, is not very helpful for policy makers before the event. Again, appeal must be made to both theory and precedent. The idea of future abuse (predation) as the intent is very unlikely. To succeed, predation requires losses by both victim and predator today so that the predator can maintain higher prices tomorrow, earning above normal profits for long enough to recover both of these losses. Entry by new rivals or chiselling by existing firms is then even more attractive and would easily defeat the project. 


\section{Restrictive practices and price discrimination}

In both the USA and the UK restrictive practices, collusion and "anti-competitive" devices were either deemed illegal from the days of the original Sherman Act (1890) or, in the case of the Monopolies and Restrictive Practices Act (1948) at the very least, subject to investigation. The UK legislation was strengthened by the Restrictive Trade Practices Act 1956 which deemed that all agreements between firms (not just the "legal" monopolies which held 33 percent [later 25 percent] of the relevant market) had to be registered officially and were presumed to be against the public interest unless the non-criminal Restrictive Practices Coun deemed them to be acceptable against a list of prescribed criteria (which included a final, 'catch-all' public-interest yardstick).

The two main additional pieces of US legislation are the Robinson-Patman Act 1936 and the Federal Trade Commission Act's ban on false and misleading advertising which resulted in major (but indecisive) investigations in the 1970 s. The Robinson-Patman Act was passed because of perceived weaknesses in the Clayton Act 1914 which prohibited price discrimination which 'substantially' lessened competition or tended 'to create a monopoly'. The Clayton Act excludes from this prohibition discrimination owing to differences in grade, quality or quantity of the good sold; discrimination which makes 'due allowance' for differences in cost; and third, discrimination 'carried out in good faith' to meet a competitor's price. Small traders were not protected since the quantity clause provides an easy escape; moreover the courts refused to apply the law when the discrimination resulted from the pressures of large traders on their suppliers. These issues became increasingly apparent with the advent of large-scale retailing during the 1920s and 1930s. The Depression coincided and the problems of small- and medium-sized buyers were compounded by the tendency of manufacturers to shade prices and give less than over rebates in the face of declining demand. The trend towards government approval of cartelization at that juncture of history was embodied in the National Recovery Administration in the USA and the RobinsonPatman Act was passed against that background.

Its main purpose was to prevent powerful retailing groups from obtaining 'undue' favours from their suppliers relative to small- and medium-sized traders. It prohibits the charging of different prices to different purchasers of 'goods of like grade and quality' if the effect 'may be substantially to lessen competition or tend to create a monopoly ... or to injure ... competition'. Another section renders it illegal for a buyer 'knowingly to induce or receive a discrimination in price'. The refunds allowed relate to perishability, obsolescence, 'due allowance for differences in the cost ... resulting from the differing methods or quantities' specific to the transaction in question, and/or that it was done in good faith to 
meet an equally low price of a competitor'. Neale (1960, pp.252-3) summarizes the case law history of the Act's application as follows:

[it] will be mer with frank unbelief. The idea that a manufacturer may break the law by granting a wholesaler's discount to a wholesaler who also runs retail shops, or by selling goods direct to retailers at a price higher than one of his wholesalers may be charging, or by beating an offer made to an important customer by a rival manufacturer or even by matching the offer unless he is satisfied that his rival can justify his low price by cost savings ... may simply seem incredible.

But incredible or not, that is the US law. The muddle is inevitable given the conflicting objectives of the Act. It is attempting to protect small business against price disadvantages on the one hand, while simultaneously attempting to combat price discrimination as anti-competitive.

The difficulty industry has with the law is illustrated by the 'good-faith' pricematching defence. To succeed, the seller must show that the matched price is itself lawful. This necessitates knowledge of the competitor's own price and cost structure - but in a classic Catch-22 if he shows he has such knowledge he may be prosecuted for conspiring to restrain trade under the Sherman Act. Further confusion is caused by the phrase 'price differences' which is used in the legislation, not 'price discrimination', which is a technical term indicating disproportionality of price : marginal cost ratios. Thus identical prices with different costs (uniform price discrimination) cannot be touched by the legislation.

In 1980 the US Department of Justice recommended repeal of RobinsonPatman, as well as the section of the Clayton Act which it had amended. But to date this has not happened. In the interim it has fallen into disuse but prior to 1980 it certainly had anti-competitive effects by deterring firms from engaging in selective price-cutting (which is one main reason why economists argue cartels cannot survive absent government regulatory support). Essentially the Act is concerned more with protecting particular competitors, rather than competition.

\section{A case study: Pharmaceutical pricing in South Africa}

In a 1994 study entitled Uniform Pharmaceutical Pricing, Ernst R Bendt, concluded (p.20) 
Uniform pricing provisions should be recognised for what they are: anti-competitive policies designed to protect a diminishing segment of the increasingly price-sensitive retail marketplace. Public policy should ...(be) encouraging more price flexibility, not less.

The South African government's National Drug Policy (Department of Health, 1996, p.8) takes the opposite view. It argues for a "single exit price" (jargon for a uniform manufacturer price) for apparently "equivalent transactions" and favours a "transparent" pricing structure for private sector purchasers in South Africa. Recently the Department of Health announced that it wishes in addition to see the conventional mark-up of a fixed percentage on retailer purchasing price (plus a nominal dispensing fee) replaced by a fixed fee for professional services.

Uniform price legislation would go far beyond current Competition Policy in that first, it would be directed at particular market practices, not at abuse of particular practices. The abuse criterion in the Competition Act would examine current or proposed market practices in the light of their ultimate impact on consumer welfare. For example, does the current of proposed practice strengthen and improve the efficiency of the existing retail sector? Does the practice encourage innovation in the existing distribution chain which would be to the benefit of the consumer (in terms of lower final prices or a better service)? Does the practice facilitate or hinder the development of more efficient means of purchasing and paying for products by the consumer or others acting on the patient's behalf, such as the managed care arms of medical schemes? Does the practice facilitate or hinder the widest possible distribution of the product in areas of the economy where conventional outlets are scarce or conventional medical scheme cover is unavailable or hard to come by? Does the practice facilitate or discourage innovative methods of monitoring pharmaceutical consumption such as total disease management, pharmaceutical benefit management or drug utilisation reviews either pre- or post-consumption by patients? Does the practice facilitate or discourage innovative distribution methods such as direct mail, health maintenance organisations, preferred providers of medicines, or entry by large-scale retailers in either CBDs or hospitals?

Clearly if a blanket rule (such as uniform pricing or a fixed fee-for-service) is applied it can have deleterious or beneficial effects on consumer welfare depending on circumstances. The legislation will then be either difficult to apply. complicated to draft or produce many and often unpredictable distortions. "Abuse" legislation is then more appropriate; and abuses can be dealt with on a case-by- 
case basis and with. a proper definition and understanding of competition consistently borne in mind.

Uniform price legislation would make it illegal to negotiate discounts on prescription medicines with retailers who can offer services to manufacturers that justify discounts. Uniform prices should be opposed as a form of price controls. They are inconsistent with the goal of strengthening competition in the private health-care sector and would curtail company pricing flexibility -- a flexibility which has been important in causing reductions in ex-factory price levels in recent years (see Reekie, 1996), and which in turn, despite many artificial rigidities in the distribution chain, has resulted in lower prices paid by patients to many previously unavailable forms of medicine distribution systems. Retail pharmacies, leading proponents of uniform pricing, are among the many businesses that now find it essential to offer discounts to their customers.

The National Drug Policy also argues for transparent pricing structures. But transparency per se is neither desirable nor undesirable in the public interest. For example, high (but transparent) price levels are undesirable. Fixed transparent mark-ups in pharmacy have been deemed to be anticompetitive (by the market place as discounts have eroded them over the last decade -- see Competition Board Report 52). Transparent fixed-fee-for-service has also been deemed undesirable in other areas of health-care provision (the Medical Schemes Amendment Act 1989 removed the legal requirement).

Appropriate or competitive transparency is where buyers, whether patients, medical schemes, pharmaceutical benefit managers, managed care groups or others, can easily obtain information on alternative services of lower price suppliers. This results in lower prices and better services as higher cost, less satisfactory suppliers are forced to cut prices to gain or retain business.

Inappropriate or anticompetitive transparency, such as collusively determined and legally guaranteed margins or fees, discourages this rivalry and preserves and conserves existing high prices and distribution modes.

The Competition Board (Report 4, p.61) writes:

... codes of conduct, 'fair trade' rules and 'open trading' systems, or whatever they may be called, tend to maintain prices at overly high and rigid levels (and) ... (it) is an intriguing fact that the powerful manufacturer and the weak trader both champion these systems. 
The preference of some traders for anticompetitive transparency to avoid rivalry has been discussed. Why would manufacturers prefer a uniform price? The Competition Board (Report 4, pp.10 and 62) notes that price discrimination by manufacturers (the converse of a uniform price for equivalent transactions) "is indispensable in the public interest". The preference of large manufacturers for an anticompetitive transparent pricing structure is understandable. Marketing, product design and sales efforts are easier to use in the guaranteed absence of price rivalry. They are less easily countered, less readily noticed when used and discourage the promotion or market entry of generics on a pure price basis.

"Secret" rebates do not remain secret for long and any rebate is soon matched. This is how competition avoids prices congealing at high levels. The need to avoid price uniformity and not to regulate against price discrimination is therefore indeed "indispensable". But the attractiveness of avoiding price competition is only one reason the Competition authorities saw price discrimination in this light (Report 4). Other arguments against an anticompetitive, transparent, uniform price include the desirability of providing cross-subsidisation to different sectors of the market which vary in their ability to pay. This equity argument partly explains the low price charged to public-sector buyers of medicines, and to dispensing doctors servicing patients for a single, allinclusive (and low) consultation fee. Total industry output is therefore increased and total consumer welfare raised. Of course the phrase "price discrimination", like the phrase "perfect competition" is emotive. It also misleads. The issue is consumer welfare.

The most common theoretical charge of abuse in any monopoly situation is that firms can reduce output and so raise price. However as Joan Robinson (1933) demonstrated, price discrimination is one business practice where it can be shown, in general, that the ability to practise it either simply enables the same output to be reallocated to different market segments (an equity or income distribution issue) or that it can permit firms to increase their output. Pure theoreticians, therefore, would concur with the Competition Board that price discrimination is, if not indispensable, at least benign. Enforced uniform pricing, on the other hand, would at best have no impact on quantity (but a negative one on equity) and at worst would be malign in its impact on quantity.

The National Drug Policy (NDP) wishes to enforce an anticompetitive transparent, uniform price, for "equivalent transactions". That wording was used first by the Minister for Public Enterprises in Government Notice No. 1136 on 24th June 1993, in terms of the Competition Act. The intention of the Notice was the same as that of the NDP, namely to make it 
unlawtul ... to sell ... medicines ... in a manner which ... discriminates between buyers $\ldots$ by applying dissimilar prices ... to equivalent transactions.

The NDP (as proposed government policy) is thus in broad agreement with the then proposed policy of the government before the 1994 election. Notice 1136 was intended to apply under existing Competition Policy legislation. It was appealed against by some but not all manufacturers. The Appeal has currently lapsed. Would the Appeal stand under existing or proposed Competicion Policy legislation?

To answer that question is difficult, but three factors make it likely that the Appeal should succeed if put before the Board. These are:

The definition (appropriately) is similar to the formal theorists' definition of price discrimination. That is, to cite Stigler (1966) it is:

the sale of technically similar products at prices which are not proportional to their marginal costs.

We have already seen how price discrimination is approved of theoretically as indispensable, how in practice it has encouraged competition, how it results in competitively transparent price reductions and in competitively transparent shifts in buyer behaviour as they exert preferences by shifting from one distribution channel to another. Both definitions (Stigler's and that of the Notice) show also that price discrimination is identified by examining ratios (price : cost), not by examining price alone. Thus identical prices can be discriminatory if costs differ. This is why the phrase "equivalent transaction" is necessary.

ii The Notice emphasised that differences in price are "justifiable" if they are required "to provide for the cost or probable cost in the manufacture and/or distribution of the medicine". The policy problem here, as both economists and the drafters of the Notice understand, is that costs are subjective. When the manager of a firm takes a decision only he/she knows the benefit he/she is foregoing - the cost - of the decision. Hence the use of the adjective "probable".

To illustrate one difficulty with uniform prices for equivalent transactions, ask "what is equivalent?" A manufacturer may wish to raise his share of the market. Should he price at the same level today to two different distribution channels if he anticipates one channel has a much higher growth potential tomorrow? If he believes the one channel has a more efficient (lower cost) method of reaching the patient and can expand 
more rapidly tomorrow than the other channel, how can he encourage that for his own (but also the final patient's) benefit? The answer is to price ahead of demand by lowering price to the channel with high potential - a common business practice with prima facie evidence of unjustifiable price discrimination. Yet closer inspection, taking account of probable costs, would render any price differences "justifiable".

Implementation of the Notice on Appeal would, therefore, be difficult since (1) it is attempting to ban a practice the Board accepts in principle as "indispensable" and (2) it would be difficult to ascertain in practice if any price differences (or uniformities) uncovered represent or do not represent price discrimination as defined both by theoreticians and the Minister in the Notice.

iii The third reason, paradoxically, is due to the current state of flux of Competition Policy. It is uncertain whether the redrafted policy will follow an "American" or "European" pattern, or alternatively retain the existing South African mode, at least on specific issues. As far as price discrimination is concerned, however, the three bodies of competition policy or law adopt a similar approach:

- USA: The 1936 Robinson-Patman Act prohibits the sale of goods at different prices to customers intending to sell onwards to final consumers, with limited exceptions (see above). This precedent would appear to be a paradigm for the uniform price proposed in the NDP. However, as we have seen the Act has proved unworkable, unenforceable and impossible to interpret. The US Department of Justice has recommended its repeal on these grounds and on the grounds that if enforced, it would be detrimental to competition. Its repeal is continually opposed by lobbies of small-scale retailers but de facto the Act has simply withered away. The consensus of legal and economic opinion is that next to the Act's repeal, benign neglect is the optimal approach from the viewpoint of the public interest and of the consumer. There is little in American precedent to encourage South African proponents of uniform pricing for equivalent transactions.

- UK: The United Kingdom Monopolies Commission in 1971 produced a multi-industry report entitled Parallel Pricing. This too provides no support for proponents of uniform pricing, indeed the reverse. Firms, it argues (para 9), often prefer to compete in ways other than price "because the cards of non-price competition are less easy to trump". That, of course, may or may not be in the consumer interest. But (para 67) each case should be examined to ascertain, for 
example, if coordinated pricing policies (to say nothing of mandated ones such as those proposed in the Notice and by the NDP) inhibit expansion of market shares by sellers of products or modes of distribution preferred by consumers; or if departures from published prices by way of discounts etc. (para 74) weaken anti-competitive, collusive or conservative behaviour; or whether differences in cost levels, managerial aspirations, market shares, expectation of future growth or management styles impact more heavily on price coordination patterns than does a desire to restrict ourput or lead a quiet life. If price competition is minimised, the Report continues. excessive costs can be built into given prices, the incentive to satisfy the final consumer and gain his/her patronage by lowering price may be weakened, and inflationary pressures may be strengthened due to an ability to pass on cost increases in a coordinated fashion (particularly if only one price controller or watchdog has to be convinced rather than a multitude of consumers or their agents with an ability to switch custom - the latter is an impossible argument for firms to counter after it has been acted upon).

- SA: In South Africa price discrimination falls under Section 1 (b) of Act No. 96 of 1979 . That is, it could be deemed to be a restrictive practice operating against the public interest. If so, it can legitimately be banned by the Minister. If not, it is then regarded as a legitimate business practice or method of trading. Taken seriatim, the seven criteria laid down by the Act to determine whether or not a practice is restrictive and against the public interest are:

- does it restrict production or distribution?

- does it limit facilities available for the same?

- does it enhance or maintain the price?

- does it prevent production or distribution by the most economical means?

- does it prevent or retard technical improvements or the expansion or opening up of markets?

- does it prevent or restrict entry into any branch of trade?

- does it prevent or retard the adjustment of any profession or trade to changing circumstances?

In each case the answer in pharmaceutical distribution is negative:

- In theory, price discrimination expands or maintains output, it does not restrict it. In practice it has been used to gain access to additional 
and novel distribution channels - health maintenance organisations, dispensing doctors, direct mail distribution, preferred provider pharmacies etc -- and these expansion modes have probably been used to a greater extent than they would have been had conventional community pharmacists not be prohibited from expanding through normal corporate means because of the regulatory ban on corporate ownership.

- Price discrimination has done the reverse of limiting facilities for production and distribution (in the face of the ban on pharmacy corporate ownership which has limited retailing facilities - to conventional small-scale retailers only).

- Price discrimination has resulted in the newer modes of distribution demanding discounts, and both the new and the older modes of distribution passing discounts on to reimbursers. It has not maintained or increased price. Ex-factory prices indeed tend to have declined (Reekie, 1996), while conventional retail markups and wholesale margins result in South African factory exit prices being among the lowest in the world when calculated as a proportion of the final price paid by patients.

- Price discrimination has not resulted in distribution through uneconomical modes. Rather it has encouraged sellers to seek out alternative and less costly modes to the outdated retailing pattern of small-scale, individually owned community pharmacies which are banned by law from operating under an ownership other than that of a pharmacist.

- Price discrimination has encouraged innovation in pharmaceutical distribution, not retarded it - dispensing doctors, mail-order pharmacists, and preferred provider organisations promoted by innovative groups such as Mediscor are just a few examples.

- Price discrimination has not restricted entry into any trade. Rather the reverse is true. Doctors qualified by competence, if not function, to dispense have done so, and pharmacists have entered into agreements as preferred providers, and also moved into direct mail dispensing as a consequence.

- Price discrimination has encouraged, not retarded, the adjustment of the retail pharmacy profession to changing circumstances.

In short, by all criteria price discrimination fails to meet the yardstick of a business practice operating against the consumers' interest. Of course, the competitive pressures observed could well have been differently and still more efficiently 
expressed had they not been legally compelled to "get around" rather than being prevented from competing head-on with conventional retailers.

Furthermore, competition policy authorities must not forget Adam Smith's dictum. While people of the same trade are motivated to meet together to raise prices, Smith emphasises that the state should do nothing to facilitate such assemblies 'much less to render them necessary'. Yet an insistence on publicly posted uniform prices for the pharmaceutical industry's sales into the private sector of the health care market, and the use of the sealed bid tender system for pricing in the government sector both encourage collusive behaviour. In the former overt collusion is made easier and cheating is simpler to detect and to punish. In the latter collusion is encouraged because the costs of not colluding, i.e. loss of an allor-nothing contract, are much greater than they are in a more normal sales relationship.

A final question remains. Has the evolution of pharmacy distribution in the last decade been optimal from the viewpoint of the consumers' interest? The answer is no not because of price discrimination, however, that has generated price and cost reducing developments - but because of the ban on corporate ownership imposed by the 1974 Pharmacy Act, which has retarded such developments.

A more detailed description of the conventional retail pharmacy market is provided in the attached table.

The Retail Pharmacy Carte] : the conflict between Official Reports and Government Support, $1962-1996$

Snyman - 1962

Commission of Inquiry into High Cost of Medical Services and Medicines

Pharmacy Act 1974

\section{Findings and Comments}

"The crux of the problem is that from the economic point of view, there are too many chemist shops ... A lower price to the public and a better living standard for the pharmacist could be attained ... by decreasing the number ..." (p.912).

Only pharmacists, not corporate personae allowed to own retail pharmacists. A "grandfather" clause permitted existing corporate owners (both in conventional shopping areas and in private hospitals) to remain, as it also did medical benefit scheme ownership, but not medical aid scheme ownership. 
The Retail Pharmacy Cantel : the conflict between Official Reports and Government Support, 1962-1996

Steenkamp - 1978

Report of the Commission of Inquiry into the Pharmaceutical Industry

Browne - 1985 Interim Report on Pharmaceutical Services “... the pharmacist is not at present being used to his full capacity" (para 525).

In earlier paragraphs Steenkamp pondered how (given modem manufacturing technology) pharmacists could "practicably" cooperate with doctors - at least outside of the hospital setting.

“...involvement of the pharmacist in the prescription of the right medicines became all the more difficult, if at all possible" (para 523).

"The problem is rather the limited volume of prescriptions mainly as a result of over-concentration of retail pharmacies in certain urban areas..." (p 9). Indeed many pharmacists (some ten per cent) had too small a turnover "to produce a profit" ( $p 81$ ). The consequence was that pharmacists wished protection from medical benefit schemes (who could own pharmacies) and from the encroachment of dispensing doctors ( $p$ 9).

Browne (p.9, para 6.10) queried whether such protection was required. "Although pharmacists emphasise the value of pharmacist's advice about prescription medicines, the patient seems to have very little interest in obtaining (it). Usually only a commercial transaction takes place."

"The committee found that in the USA, the (sic) restrictive pharmacy ownership increased the consumers" medicine cost by approximately $10 \%$. Therefore, the Committee recommends (that) a pharmacist, whilst preserving his professional authority, should be allowed to contract his services, for his own gain, to nonpharmacists..." (p.341 para 112). 
The Retail Pharmacy Cartel : the conflict between Official Reports and Government Support, 1962-1996

Pharmacy Act 1974, No. 53 Amendment Bill 1993.

Melamet - 1994 Commission of Inquiry into the Manner of Providing for Medical

Expenses

Broomberg-Shisano 1996

Restructuring the National Health System for Universal Primary Health Care
This Act, if passed, would have permitted corporate ownership, and allowed medical schemes to own and operate pharmacies. It was withdrawn by President de Klerk and acting Health Minister, Adriaan Vlok, during the hospitalisation of Health Minister Rina Venter.

The Report reads as follows (pp.38-40)

'The largest item of expendinure by medical schemes is medicines ... One informed witness, referring to the withdrawal of the ... Amendment Bill ... argued that "the interests of 2800 or so retail pharmacists are being put before the 7,5 million members and dependents of medical schemes ..."

"The view that monopolistic mark-ups exist in the private sector, reinforced by regulatory protection of existing distribution technologies, is further underscored by the advent of new forms of distribution which have escaped the regulatory net. Whereas in the early 1980s nearly all private sector sales passed through retail pharmacists, by 1993 this had fallen to $41.33 \%$ by value, with $42.89 \%$ being paid out to dispensing doctors."

"This is evidence that high mark-ups have attracted new forms of distribution into pharmacy and that competitive forces are at work. The Medical Schemes Amendment Act would have enabled medical schemes also to enter retail pharmacy readily had the Pharmacy Act Amendment Bill not been withdrawn."

Recommended (p.57) that "pharmacies may be owned by any legal persona". 
Competition Board Report 52, 1996

Investigation to Determine Whether any Restrictive Practices ... Exist ... in the Supply and Distribution of Medicine
Page 2 of the Report notes that in South Africa there are 91 pharmacies per 100000 people while in the UK the equivalent figure is 12 . This overtrading has resulted in high costs and gross margins of up to $74.5 \%$. However, substantial deregulation has occurred leading to these margins falling to $29 \%$. In particular price competition is no longer frowned upon since

i. advertising of price is now allowed

ii. Preferred Provider Organisations (PPOs) can be set up - an activity this Report could curtail

iii. dispensing practitioners exist

iv. mail order dispensing has arisen.

On p. 7 the Board acknowledges that medicine costs in the private sector are proportionately very high by world standards.

On p.23 the Board notes that the regulatory regime militates against competition and that the pharmacy profession "remains unmoved on the key issue of retail pharmacy ownership". But the ownership regulations are preventing income maintenance by retailers. Income maintenance can only be achieved by concentration of outiets and growth of the survivors.

On pp. 11-14, a listing of complaints received from retailers is given. They include establishment of PPOs, mail order dispensing and other distribution channel innovations.

The Board defines a PPO (Preferred Provider Organisation) network as operating in two ways -

1. open membership to all pharmacies who request to join and qualify on certain criteria, and

2. restricted membership where in addition a quantitative restriction on the number of pharmacies applies. 
Most complaints revolved around the latter.

In para 64 (p.17) the Board expresses concern at the impact on competitors (retailers not included in the $\mathrm{PPO}$ ). It does not mention the impact on patient costs. Rather 'the effect of this restriction (Mediscor's PPO) may be ... that the number of retail pharmacies could be reduced".

On p.22 the Board notes that thanks to PPOs and other distribution innovations coupled with deregulation, drug costs have declined. The drug spending may have fallen from $33 \%$ of medical scheme expenditures to $25 \%$ and is possibly on track to $15 \%$.

On p.31 this positive result is ignored and the Board notes only, and with implicit approval, that Mediscor may have now ceased to regard the operation of a PPO as a main focus of its business. Rather it may intend to use its network simply for claims processing on which it will earn commission income. On p.32 the Board concedes that the needs of cost containment have to be weighed against the harm to retailers. But despite the evidence the Board "is satisfied that a closed panel (PPO) is not a prerequisite for cost containment". 


\section{CONCLUDING THOUGHTS}

Competition policy in South Africa is in a state of flux. In 1996 new legislation was drafted and withdrawn. The existing legislation (essentially the 1979 Act) remains in place, and although further new legislation was promised by the end of 1996, it is likely to be implemented only in mid-1997.

Public opinion about what Competition Policy is or should be is also in a state of flux. Influential opinion-formers range from those who are simply anti-big business to those who would take a pragmatic stance, issue by issue, to those who adopt a Panglossian approach that whatever is, must be optimal. Some argue that existing policy is sensibly flexible. Others believe the allegedly "rigorous" American antitrust laws should be translated to South Africa, while still others would have South Africa model itself on the more "behaviourally" oriented approach of some European legislators.

There are many fallacious and internal inconsistencies in the arguments being put forward in the debate. For example, the anti-big business lobby overlooks the fact that a "big" firm in South Africa may simply appear big because the market is so small. A smaller firm in that context may simply be inefficient. Those who argue for the "rigorous" American antitust system are referring to the rigours of forced divestiture or trust-busting, but judgements of that sort have not been made in American courts for some 70 years, and the last attempted case of that kind, IBM, was rejected in 1981 after 13 years of litigation.

In fact, in the last quarter of the century the USA has indeed proved to be "rigorous" in its application of its laws, but its "rigours" have not been in the stiffness or harshness of judgements and sentences, but rather in the rigorousness with which it has applied economic analysis in its procedures and arguments prior to arriving at conclusions. (Former US Solicitor General Judge Robert Bork, in the 1993 edition of his 1978 book surveying 100 years of US legislation, provides case-by-case support for the thesis that economic reasoning has pervasively and surely become the yardstick by which the Antitrust Laws are applied.)

However, rigorousness in the use of economic analysis is not what many South African commentators mean when they use the word "rigour". By and large they mean tough attiudes to break-up, and an "incipiency" approach to merger, as illustrated by the working paper on future South African competition policy by Fourie, Lewis and Pretorius $(1995$, p.22). They wrote: 
One option would be to judge dominant enterprises on the basis of their structure alone, without reference to their conduct. (This is the approach followed in the US.)

Although this approach (misleadingly labelled American) is still popular in some quarters, Fourie et al (p.23) proposed instead the "abuse approach". Abuse could be defined as "exploitative", "exclusionary" and "structural". The abuse would be one of "dominance", and "presumptions" would be required in any new legislation to define "dominance" or the market-share level at which investigation would be triggered. Some commentators have called that the European approach. Certainly "presumptions" of legal monopoly exist in the UK (for investigative purposes) when market share hits 25 per cent (originally 33 per cent). However, the "presumptions" implying definitions of abuse would be mechanistic. Fourie et al (p.23) argue that a "clearer definition of abusive behaviour" would enable "enterprises to organise their conduct accordingly".

It is of course possible to provide clear definitions. Yet the essence of competition is that entrepreneurs do the umpredictable in order optimally to meet consumer requirements. Presumptions and definitions may simply exclude surprise, they may simply inhibit ex ante certain types of behaviour which, ex post would be interpreted as competitive. Altematively, a code of presumptions of dominance or abuse might, in the long run, be simply ignored (as is RobinsonPatman) although in the shon run it will have significantly damaged competition.

Similarly, under restrictive practice legislation vertical restraints and price discrimination would probably be banned per se. But we have already seen that to practise vertical restraints is usually irrational for a profit-maximising businessman, whilst price discrimination tends to be neutral or expansive in terms of output.

The draft bill based on the Fourie et al working paper was rejected by the Minister of Trade and Industry in late 1995. Work was begun on the second redraft in 1996. In the meantime, it was announced in July 1996 that the task force formulating the new legislation had recommenced its work for a third time. Their most recent working document highlights the dichotomy the policy-makers face. It argues that government must take a political decision as to whether the legislation should have "an exclusive economic focus or should serve political and social goals". This is the dilemma. Early US antitrust judgements were whimsical and unpredictable, varying with the dominant politically appropriate view. Later US judgements have been tackled from an economic point of view. This newer South African document veers towards that approach and states that competition law should promote 
...consumer welfare and economic efficiency by preserving the freedom of economic action of market participants. One will need to consider whether it is necessary to target excessive conglomeration and/or enterprises ... in a monopoly situation, what factors are relevant in deciding whether a merger restricts competition to a substantial extent, and under what circumstances mergers that restrict competition ... or result in market dominance ought to be condoned.

If this stance is indeed ultimately adopted, then the 1979 Act will be little amended in intent, albeit physically it may be substantially rewritten. If the political decision swings the other way then the current concern will continue.

What is required is not the impossible (and undesirable) - namely that all aspects of monopoly control should be expressed in universally applicable laws and regulations. Rather the aim should be confined to promoting competition. A sustained effort to building up a coherent body of decisions and of guidelines for them should be made. This will give assurance of as much consistency founded on economic analysis and experience as can be made. In effect little amendment of the original 1979 Act is required. Even the Board's view of concepts such as the "public interest" occur seldom in the existing legislation but have rather accumulated over the years in Annual Reports. If these views are correct they will stand, if not they will depreciate in the face of later economic arguments.

Some earlier Reports of the Board may not have received the attention they deserve (e.g. Repor 4). As a consequence inconsistent judgements have been given. Inconsistency, however, can be corrected. Inappropriate drafting of inflexible presumptions cannot.

That South African Competition Policy is imperfect is not questioned. That the overall objective of the Act - Maintenance and Promotion of Competition requires rejection is unacceptable. Racher, what is required is a regular and more consistent application of economic principles. Cross-referencing and frequent consultation of existing precedents and works of analysis by the Board should be expected. This will result in more predictable and more appropriate Board verdicts, whilst previous errors will be corrected in the light of better understanding.

Government (and business) resources can then be put to better use examining anti-competitive structures and practices in state-protected industrial or professional environments (including the nationalised industries and parastatals as well as protected cartels like the pharmacists). And per se illegalities in business behaviour which have been declared in minor amendments to the 1979 Act can be questioned as to their appropriateness and consistency with the overall objective of promoting competition in the principal Act. 
As Judge Bork emphasised (p.422), a competition policy that opts for openness of markets reflects the ideal of equality of opportunity. Those who argue for a structuralist approach to antitrust and for per se declaration of behavioural illegalities are more concerned with the small and less efficient, i.e. they have a preference for equality of outcome. Economic rigour demands that policy concern itself with the smallest economic unit of all, the individual consumer and his or her welfare.

\section{REFERENCES}

1. BENDT, ER (1994). Uniform Pharmaceutical Pricing. American Enterprise Institute.

2. BORK, RM (2nd ed.) (1993). The Antitnust Paradox. Free Press.

3. FOURIE, FCvN; Lewis, D and Pretorius, WJ (1995). Towards Competition Policy Reform in South Africa (mimeographed).

4. LEACH, DF (1994). The South African Cement Cartel : A Critique of Fourie and Smith. South African Journal of Economics.

5. National Drug Policy (1996). Department of Health.

6. NAUDE, SJ (1986). South African Competition Policy: Challenges and Pitfalls. Modern Business Law, July.

7. NEALE, AD (1960). The Antitrust Laws of the US. Colchester, Utrecht.

8. REEKIE, WD and CROOKE, JN (1995). Managerial Economics (4th ed). Prentice Hall, Hemel Hempstead.

9. REEKIE, WD (1996). Medicine Prices and Innovations : An Intemational Survey. Institute of Economic Affairs, London.

10. Robinson, J (1933). The Economics of Imperfect Competition. Cambridge University Press, Cambridge.

11. STIGLER GJ (1966). The Theory of Price (3rd ed). Macmillan. 